\title{
Research on the Cultivation and Promotion of the Independent Learning Ability of Design Major Undergraduates in Colleges and Universities from the Perspective of the Integration of Production and Education
}

\author{
Bailin Xiao ${ }^{1, *}$ \\ ${ }^{1}$ Northeast Electric Power University, Jilin, Jilin, China \\ "Corresponding author. Email: 531135589@qq.com

\begin{abstract}
The ability of independent learning is the foundation for students to realize lifelong learning, and it is of great significance to the growth and development of students. This paper analyzes and summarizes the problems existing in the process of independent learning of design majors in colleges and universities, and proposes countermeasures for the cultivation and improvement of students' independent learning ability under the current view of the integration of production and education. First of all, it is necessary to respect the status of students as the main body and build an open education system. Second, it is also a necessity to integrate independent learning resources and build a multi-channel education platform. Finally, it is a must to focus on the improvement of students' professional abilities and create an independent learning support service system.
\end{abstract}

Keywords: Integration of production and education, Independent learning ability, Design majors.

\section{INTRODUCTION}

As a behavior and activity that satisfies and beautifies people's production and life, design emerges simultaneously with the origin of mankind, runs through the development history of mankind, and is one of the driving forces that promote social progress and promote the development of mankind. The purpose of design behaviors and activities is to satisfy and beautify the material and spiritual needs of mankind. Affected by the rapid economic development on the demand for design talents, China's design art education has developed vigorously. The goal of training design talents in colleges and universities is to train applied professionals with good scientific and cultural literacy, keen aesthetic ability, creative thinking methods, and proficient mastery of the

*Project: This article is the phrased result of the 2020 Northeast Electric Power University Teaching Reform Project: Research on the Cultivation of Independent Learning Ability of Design Majors in Colleges and Universities (Project No.: J202060). comprehensive qualities of the professional technical ability. As a new force in the development of the creative design industry in the future, cultivating and improving the independent learning ability of design students is not only the basis for improving the quality of design education in colleges and universities, but also the key to the sustainable development of the social cultural creative industry.

\section{CONNOTATION OF INDEPENDENT LEARNING ABILITY}

Independent learning ability is a comprehensive learning ability in which students independently plan, consciously manage, and actively implement their own learning process, and take the initiative to be responsible for the learning results. It is the foundation of lifelong learning and is of great significance to student growth and development. Independent learning mainly has the characteristics of effectiveness, initiative and relative 
independence. First of all, independent learning requires students to achieve the desired learning effect through self-arrangement and self-regulation, and to ensure the effectiveness of learning in the process of realization. Secondly, independent learning is a proactive learning behavior, which is out of the scope of standard classroom learning. The entire learning process is completely controlled by the students themselves with subjective initiative, without affecting by external pressure and management requirements. In addition, students still need the guidance of the teacher in the process of independent learning, and the teacher must also give certain guiding opinions in terms of learning content, learning strategies, and learning time, so their independent learning is relatively independent.

\section{PROBLEMS EXISTING IN THE PROCESS OF INDEPENDENT LEARNING OF DESIGN MAJORS}

The rapid development of the art design industry and the large employment industry span have virtually increased the difficulty of employment for design majors, and also put forward higher requirements for students' sustainable development capabilities. The cultivation of independent learning ability is the foundation for students to achieve sustainable development in the future. First, the researchers analyze the problems existing in the independent learning of design majors.

\subsection{Uneven Learning Foundation}

Design is the unity of science, technology and art, and requires high comprehensive quality of students, especially artistic design and creative expression ability. The improvement of design heritage and artistic accomplishment relies on professional education on the one hand, and on the other hand, students' own comprehension ability. Therefore, the level of professional ability and the difference in learning background are the influencing factors in the process of students' independent learning.

\subsection{Weak Independent Learning Awareness}

The rapid development of society and economy has triggered explosive growth in design requirements. The particularity and cutting-edge of the development of the industry determine that if designers do not have enough independent learning capabilities, it will be difficult for them to adapt to the pace of development of the design discipline, let alone the ability of innovation and creation. Affected by the traditional education system and education model, students have become accustomed to passive learning. Most students think that it is enough to complete the learning tasks assigned by the teacher, or attribute learning to the need for obtaining a diploma or employment, rarely take the initiative to learn again, and lack the awareness of independent learning and the ability to think independently.

\subsection{Unclear Learning Goals}

Students' lack of interest in learning and their own lack of clear learning goals are one of the main factors that affect their independent learning. On the one hand, the transition from test-oriented education in high school to professional education in colleges and universities, students themselves lack clear learning goals and fail to recognize the needs of personal development. As a result, students will not take the initiative to explore the problems encountered in learning, and show a kind of indifferent or coping style to learning. Because there is no clear learning goal and no high requirements for future development, they have serious mistakes and delays in learning. "Procrastinators often lack metacognitive strategies and cannot effectively self-monitor learning. They have certain difficulties in time management, emotional regulation, and elimination of interference."

\subsection{Weak Independent Learning Continuity}

The cultivation of independent learning ability is a gradual process, which requires long-term persistence and gradual development of good learning habits. However, in the actual learning process, students usually complete the learning tasks according to the teacher's guidance and lesson plans. Most of the things they solve after class are the knowledge involved in the course, and they rarely think about problems and learn actively. Even with a certain awareness of independent learning, it is difficult to form long-term and continuous learning due to unclear learning goals, which is not conducive to the improvement of their independent learning ability. 


\section{CULTIVATION AND IMPROVEMENT OF STUDENTS' INDEPENDENT LEARNING ABILITY UNDER THE INTEGRATION OF PRODUCTION AND EDUCATION}

The vigorous development of the design industry not only requires a large number of design talents, but also puts forward higher requirements on the comprehensive ability and professional quality of design talents. That is, when they leave school and enter society, they can still play their subjective initiative of learning in the unknown areas of the design industry, improve their professional abilities, enrich their subject expertise, and improve their work projects. Multidepartmental, multi-level, all-round joint construction based on the integration of industry and education to develop the independent learning ability of design majors plays an extremely important role in optimizing the teaching structure of design, and cultivating students' innovation and entrepreneurship capabilities, and the habits and capabilities of lifelong learning.

\subsection{Respecting the Status of Students as the Main Body and Building an Open Education System}

Psychologist Carl Rogers mentioned in the book "Autonomous Learning": "People are born with the potential to learn. The task of teachers is not to impart knowledge, but to allow students to learn independently and meet their needs, so that students can actively participate in learning and develop their ability to learn independently." Independent learning ability emphasizes the conscious learning process of a student, a process of awakening the desire for knowledge. It can stimulate students' internal learning motivation. Maintaining the lasting motivation of independent learning is the original motivation to promote the quality of independent learning, and it is the basic prerequisite for students to learn to study. To cultivate students' autonomous learning ability, the first is to establish the student's dominant position in teaching, let students become masters of learning activities, develop and cultivate their autonomy, initiative and creativity, and make students become the main body of educational activities and selfdevelopment. The duty of a teacher is no longer just to impart knowledge, but also to be a tutor for students to carry out learning and a provider of learning resources. Professional teachers should strengthen the guidance of students' independent learning, help students set appropriate learning goals, formulate scientific and reasonable learning plans, and guide students to correctly choose the content and strategies of autonomous learning. They should also guide students to correctly evaluate the results of independent learning, and play the role of teachers' guidance and supervision. Through the guidance of teachers, students determine their learning needs, set learning goals, master learning resources, obtain and use learning opportunities, and self-evaluate the results of learning.

\subsection{Integrating Independent Learning Resources and Building a Multi- channel Education Platform}

In the process of "independent learning", learners need to exert their subjective initiative, independently choose the knowledge and skills they need to learn, and realize self-control, selfmotivation, and self-assessment in the learning process. Independent learning is not carried out in isolation. Its existence requires a harmonious educational environment, that is, the schools must provide students with sufficient learning autonomy and educational resources that are conducive to student growth in order to create a good atmosphere for independent learning and self-development. Based on the characteristics of design disciplines, students are encouraged to actively use public independent learning platforms and resources for learning. Colleges and universities should also rely on the campus network platform to further increase the construction of the schools' independent learning platforms and auxiliary teaching platforms, develop curriculum learning resources, and expand the network sharing space for independent learning. The training of design talents should be based on whether they conform to the development of the industry as the standard, and must rely on the development of the industry to achieve the goal of talent training. It is necessary to introduce design companies to directly participate in the training of talents, understand the needs of talents, and take the road of talent training that emphasizes ability, practicality and innovation. Schools should take the initiative to strengthen cooperation with enterprises and form a good talent sharing mechanism. By leading students to contact the market, contact companies, enter design studios, carry out competition project training, participate in actual project operations, etc., it is a must to fully 
mobilize students' learning enthusiasm, enhance learning motivation, and change passive learning to active learning. Through platform construction, students can be guided from other control to selfcontrol, and clarify the goal of independent learning.

\subsection{Focusing on the Improvement of Professional Ability and Creating an Independent Learning Support Service System}

Independent learning requires students to make choices and control over all aspects of learning as independently as possible in the learning process, and to independently carry out learning activities. However, this kind of independence is not separated from school education and teacher-guided learning. The teacher's guidance plays a vital role in promoting students' independent learning. Teachers should respect the right of students to learn independently, develop the spirit and motivation of independent learning, research, and innovation contained in the students themselves, and encourage them to guide them in the right direction. The professional nature of the design discipline requires students to have design practical skills, creative creativity and social practical skills. The acquisition and improvement of these skills rely to a large extent on students' independent learning and mastery. The independent learning support service system is established under the macro-control of the college. The persons in charge of each discipline should put forward specific requirements for the establishment, operation and management of the entire system, and taking students as the leading factor to achieve the training of professional practice ability and improve the comprehensive quality of students through the establishment of design teams, design studios, professional associations and other cooperative teams. The educator Makarenko pointed out: "Cultivating a serious sense of responsibility is an educational method to solve many problems." The establishment of an independent learning support service system, on the one hand, is able to cultivate students' strong sense of mission and responsibility, organically integrate independent learning with growth and become talented, form a benign interaction with the society with a developmental attitude, guide students from wanting to learn, eager to learn to enjoy learning, and realize the cultivation of independent learning ability in the true sense. On the other hand, it can cultivate students' practical ability to be good at teamwork and communication, and cultivate their excellent qualities of mutual cooperation, mutual respect and mutual learning in the process of project completion. Through the feedback of project results, students can gain self-motivation, selfassessment, and self-feedback learning habits.

\section{CONCLUSION}

At present, the wave of economic globalization, education internationalization, and informatization is impacting traditional education and learning models. In a learning and knowledge-based society, the responsibility of university education is not only to impart knowledge to students, but more importantly, to enable students to master the ability to learn independently. Especially in the process of cultivating design professionals, the cultivation of independent learning ability can not only make up for the individual differences between students, but also effectively improve the learning ability and practical ability of students. Through their own active learning, students have expanded their knowledge outside the classroom, and can also build firm confidence to explore suitable development pathways for their success in the future.

\section{AUTHORS' CONTRIBUTIONS}

This paper is independently completed by Bailin Xiao.

\section{REFERENCES}

[1] Zhao Shujie, Hong Bo, The Necessity and Feasibility of Cultivating College Students' Independent Learning $[\mathrm{J}]$. Journal of Educational Institute of Jinlin Province, 2015(09): 15-16. (in Chinese)

[2] Zeng Xiaoquan, Improving Self-developing Capability in Art Design Education [J]. Higher Education Forum, 2010(02): 30-32. (in Chinese)

[3] He Wuhua, On Developing Academic Attainment of University Students in the View of the Learner-centered Idea [J]. Educational Research, 2013(03): 106-111. (in Chinese)

[4] Jiang Lingling, A Brief Talk on the Status Quo of College Students' Autonomous Learning Ability and Research on Cultivation Ways [J]. Jilin Education, 2021, (Z2):108-109. (in Chinese) 
[5] Liu Yanhui, A Probe into the Cultivation Mode of College Students' Autonomous Learning Ability in Reverse Classroom [J]. Journal of Educational Institute of Jilin Province, 2020, 36(01):149-152. (in Chinese)

[6] Zhang Jihong, Cultivation and Improvement of College Students' Autonomous Learning Ability under the Integration of Production and Education [J]. Heihe Journal 2020, (01): 161-163. (in Chinese) 